\title{
Correction to: Interactive effects of personal resources and job characteristics on mental health: a population-based panel study
}

\author{
Anja Limmer ${ }^{1} \cdot$ Astrid Schütz $^{1,2}$ (D) \\ Published online: 8 April 2021 \\ ○) Springer-Verlag GmbH Germany, part of Springer Nature 2021
}

The original article was corrected.

Publisher's Note Springer Nature remains neutral with regard to jurisdictional claims in published maps and institutional affiliations.

The article: Interactive effects of personal resources and job characteristics on mental health: a population-based panel study was written by Anja Limmer, Astrid Schütz was originally published electronically on the publisher's internet portal (currently SpringerLink) on 6 June 2020 without open access.

With the author(s)' decision to opt for Open Choice the copyright of the article changed on 15 February 2021 (C) The Author(s) 2021 and the article is forthwith distributed under the terms of the Creative Commons Attribution 4.0 International License (http://creativecommons.org/licenses/ by/4.0/), which permits use, duplication, adaptation, distribution and reproduction in any medium or format, as long as you give appropriate credit to the original author(s) and the source, provide a link to the Creative Commons license and indicate if changes were made.

Open Access This article is distributed under the terms of the Creative Commons Attribution 4.0 International License (http://creativecommons.org/licenses/by/4.0/), which permits unrestricted use, distribution, and reproduction in any medium, provided you give appropriate credit to the original author(s) and the source, provide a link to the Creative Commons license, and indicate if changes were made.

The original article can be found online at https://doi.org/10.1007/ s00420-020-01555-0.

\footnotetext{
Astrid Schütz

astrid.schuetz@uni-bamberg.de

1 Department of Psychology, University of Bamberg, Bamberg, Germany

2 Chair of Personality Psychology and Psychological Assessment, University of Bamberg, Markusplatz 3, 96047 Bamberg, Germany
} 